International Journal of Arts and Humanities Studies (IJAHS)

ISSN: $2754-4311$

DOI: 10.32996/ijahs

Journal Homepage: www.al-kindipublisher.com/index.php/ijahs

\title{
Reconstruction of the Civic Virtues of Several Ethnicities, as a Strengthening of Pancasila Mutual Cooperation Democracy
}

\author{
Hari Zamharir, Zulkarnain \\ Faculty of Social and Politic Science, Universitas Nasional, Indonesai \\ $\square$ Corresponding Author: Hari Zamharir, Zulkarnain, E-mail: zulkarnain@civitas.unas.ac.id
}

\section{ARTICLE INFO}

Received: 08 October 2021

Accepted: 22 November 2021

Published: 04 December 2021

DOI: $10.32996 /$ ijahs.2021.1.1.15

\section{KEYWORDS}

Civic virtues, ethnicity, the path of modernization, liberalization, mutual democracy

\section{ABSTRACT}

The long road of economic and political modernization of democracy in Indonesia has transformed Indonesian society into an industrial society that has not empowered the people's economic sectors. The ups and downs of democratic politics remain far from the culture of deliberation mandated by Pancasila. The combination of development politics that has hit collective economic, cultural wisdom with political liberalization in the past 15 years has negatively impacted Indonesian cultural identity. The following study seeks to reconstruct the local wisdom and political values of Indonesian ethnic groups and communities to demonstrate the potentials of social capital to improve our democratic politics. The object of the study consists of two types: the first is ethnic groups, with a focus on Wajo and Minang, the second is the communities of several urban parks in Java. The theoretical perspective used is the theory of deliberative democracy. From the point of view of political anthropology, this study is a case study in the context of qualitative research with qualitative-interpretive methods.

\section{Introduction}

The scientific study of voluntary associations based on ethnicity and then succeeded in playing national politics in Surname from an anthropological perspective was brilliantly carried out by the famous Indonesian anthropologist Parsudi Suparlan (1975). The case of such a political role is uncommon. In quite several cases, latent or manifest ethnic identities lead to conflict. In Java, for example, cultural divisions (sub-cultures) are in the form of Javanese people who have solid Islamic diversity (Santri), whose Islam is thin (Abangan), and sorting based on high social class (Priyayi). For example, the cultural conflict and group interest in Ngandong Village, Klaten, occurred in the Post-Suharto era-and the explanation for this conflict goes beyond the classic Clifford Geertz trichotomy approach, namely the cultural conflict of the Santri, the Abangan segment of society, and the Javanese in the upper stratum, Priyayi Permana, (2010). Why go beyond the Santri-Abangan-Priyayi trichotomy approach?

In contrast to the existence of the three classical sub-cultures in Java, Indonesian society is now experiencing the complexities of development in culture and, at the same time, experiencing distractions in their political life. In the Javanese context, the conflict in Ngandong Village in Klaten, Central Java also involved village "priyayi" who, with their historical experience of modernization, had views on modernity and aspirations to achieve their progress; as well as those belonging to the santri and take care of the abangan Muslims.

The illustration above is not meant to mention the issue of SARA. The focus of the message from this illustration is about the village policy of building a chapel in Ngandong Village, which was determined without adequate deliberation. The illustration in the background above is an excerpt from the many problems of malpractice of democracy. It is the disappearance of civility and noble values or civic virtues of various sub-cultures, ethnicities, or ethnic groups Abdullah, (2014).

Another illustration of the malpractice of deliberation is in the mechanism in the Musrenbang (Development Planning Consultation). At the planning level at the central level, through BAPPENAS, a conception of participatory development is adopted, which assesses the centrality of public involvement in development planning. However, at the ministry level, under the coordination of the Ministry of Home Affairs, the Murenbang mechanism indicates the cessation of public involvement in the final stages of

Copyright: (C) 2021 the Author(s). This article is an open access article distributed under the terms and conditions of the Creative Commons Attribution (CC-BY) 4.0 license (https://creativecommons.org/licenses/by/4.0/). Published by Al-Kindi Centre for Research and Development, London, United Kingdom. 
formulating development plans and decisions. See the results of the joint research paper; see (Zuhro et al.) Zamharir and Sahruddin's (2015) study of the political products of the MPR also shows that the understanding of the Fourth Precepts of Pancasila and its implementation is also problematic; the mandate of a talking-centric democracy is poorly understood and tends to deviate towards a voting-centric democracy. With such a misconception, the derivative product is legislation and implementation of democracy, which relies more on representative democracy and democratic practices that marginalize the nation's noble values.

It can be seen that there is a need for our democracy to be extracted from the noble values of Indonesian tradition. Corrective steps certainly need to be taken to clarify what noble values, civility, or civic virtues exist among ethnic groups in Indonesia. This study intends to reconstruct this matter. In the idiom of legal experts, it is said that values and norms in society are the raw materials for formulating favorable laws. Thus, civic virtues among ethnic groups serve as raw materials for strengthening the conception and practice of democracy by the Pancasila mandate. How can a reconstruction be conclusively produced? First, from the theoretical aspect, this study will use the theoretical perspective of deliberative democracy, which is the most recent development (state of the arts) of democratic theory. Second, a political, anthropological approach to understanding political culture among several ethnic groups and communities will be used.

New research is worth doing if it touches at least one of these two traits: urgent and interesting Siregar et al., (2021, p. 51). The contribution of this study is the shooting and re-emergence of the nation's noble values that are carried out within the framework of political anthropology, with in-depth interpretations. Then this photo will show its potential to strengthen our conceptualization and understanding of the democratic mandate in the Fourth Precepts of Pancasila; also, it's potential to encourage the practice of community consultations or deliberation, both at the community level and in the formal political process.

\section{Literature Reviews}

The first is about the concept of civic virtues. From the Oxford Dictionary, it can be concluded that civic virtues are values and behavior with high moral standards in interactions related to public affairs. A well-known term in our society is the noble values of the nation. The word civic means: (1) relating to a city or town, especially its administration; municipal; and (2) relating to the duties or activities of people concerning their town, city, or local area. Virtue means behavior showing high moral standards, excellent or helpful quality of a thing.

The term related to civic virtues is civility. From the Oxford Dictionary, the term civility means (1) formal politeness and courtesy in behavior or speech; and (2) polite remarks used informal conversation. In Indonesia, it is generally equated with civility. This paper is understood as civilized attitudes and behavior in social interactions, especially in speech and behavior. It should be added that at first, civility was strongly associated with civilized citizenship; the meaning of politeness appears later (Late Middle English: from Old French civility, from Latin civilitas, from civilis 'relating to citizens' (see civil). In early use, the term denoted the state of being a citizen and hence good citizenship or orderly behavior. The sense of 'politeness' arose in the mid 16th century). With this addition, the meaning of origin seems to be used in Indonesia as the civility of a citizen.

Michael Morfit (1981, p. 843), in his study, found deliberative democracy in Pancasila. The latest theory of democracy is called the theory of deliberative democracy (TDD). TDD was developed by Habermas, Cohen, Bohman, and others. In his study, Michael Morfit (1981, p. 843) concluded that the fourth principle of Pancasila has long rejected liberal democracy. "The word musyawarah is one connoting discussion and deliberation amongst members of a society....".

The main concepts of TDD are (1) belonging to the talking-centric group; (2) public-spiritedness; (3) deliberation capacity; (4) wider public segment involvement; and (5) the local cultural context. In her article on TDD, Simone Chambers (2003) mentions that "it is now commonplace to talk about the deliberative turn." It should be clarified at the beginning of the presentation about TDD that in a simple concept, there is a difference between the concept of "participatory democracy" and "deliberative democracy," as follows:

Dryzek (2005) from the Australian National University wrote an article, "Deliberative Democracy in Divided Societies: Alternatives to Agonism and Analgesia." He seems to have found that many peoples in multicultural countries (from Malaysia in Asia to Switzerland in Western Europe) have managed to overcome the challenges of the political field intelligently and wisely, by utilizing their respective cultural resources, namely by taking a functional political path. With Lijphart's consociational democracy in Western Europe also being discussed, Dryzek then explained the solutions offered by the theoretical approaches and concepts of deliberative democracy. First, Dryzek argues that for deliberative democracy, there is a particular context in which the politics of a nation exists-namely that politics has been institutionalized with the specifics created by each nation; Differences in views between people can be compromised through communication and discourse within the framework of interpretation through language through the process of intersubjectivity. The quality of the communication referred to is communication that (1) is capable of encouraging reflection among participants; (2) the nature of the communication is non-coercive (coercive, the language of power) and (3) able to relate specific "local/group experiences" with "normative ideas/principles or values that are more general. Second, in order to achieve a contextual and reasonable democratic system and culture in heterogeneous nations. It is needed to 
replace the idea of electoral democracy (or politics to compete through elections) with electoral engineering. What Dryzek wrote is the proposal of Horowitz and Reilly (a kind of placement the status of life or the political process of a nation as a means of educating citizens towards a better perspective; analogous, perhaps, to a school or school of law in the world of law that places law as social engineering). Dryzek then mentions the forms used in Papua New Guinea and Northern Ireland.

Baiocchi Wright, (2003) describes TDD as follows: "Deliberative democratic theory refers to a body of political thought that seeks to develop a substantive version of democracy based on public justifications, more discourse-based democracy. It calls for the deliberations of the citizen as reasonable equals in the legitimate exercise."

The practice of deliberative democracy and an egalitarian culture-or in the concept of what Habermas has recently called a public deliberative space, replacing a bourgeois public space-seems to have arisen at the beginning of industrialism in England. T. Christy, in a book review, makes an analysis of Deliberative Democracy in coffee shops in England. This is related to the tradition of the elite class in England, fond of strange items from the East (Islamic Turkish civilization), including coffee. The urban masses imitate drinking coffee in coffee shops; coffee shops become "markets for exchanging information and public discussion." In reviewing this book, Christy agrees with Cowan, who uses the lens of deliberative democracy theory.

"Cowan provides an interesting overview of the growing public political participation in urban communities. There is a tendency that Cowan continues Habermas' idea that the coffeehouse functions as a place for the actual exchange of information that partially obscures the origins or status of people when they enter the coffee shop" Chris, (2006, p. 239).

In the end, Christomy notes: "Cowan explains in Habermas style that 'fluid' and 'cool' public participation, which can involve all social strata, needs to be 'brewed, and 'shuffled' continuously. have an important role in building civil society" Christomy, (2006, p. 240).

It can be said that TDD is directly related to the theoretical concept between community culture and democratic theory-as the embodiment of a democratic model that is different from democracy within the framework of liberal democratic theory. In this regard, it would be appropriate to mention an ad hoc thesis from a Malaysian researcher on electoral democracy in a multi-ethnic context in the State of Sarawak. In the eyes of Sulaiman and Othman (2009), the politics of power in elections in that state-with a focus on studies that include "leadership, ethnicity, and safety"—needs to be studied with a non-Western perspective. Sulaiman and Othman's ad hoc theses would be sufficient to confirm the need to develop models of democracy based on various ethnic cultures. By non-Western perhaps meant not to be fixated on the established normative concepts that developed in the West. It is crucial to consider the dynamics of ethnic politics more proportionately; that "ethnicity factor is an important principle that is quite dominant in the context of a general election and political development in Sarawak" (Sulaiman \& Othman; 2009, p. 3).

The Revitalization Function of Democratic Theories. TDD as a theory of democracy contains concepts aimed at deepening and straightening representative democracy. The theoretical concept of what is called "deliberative democracy" can be said to be driven by the spirit to revitalize democratic politics by discussing public affairs in a good way without being overly motivated by the will to win for the sake of the group; also the focus is on "what is said" not "who is speaking."

In the context of Taiwan, the deliberative democracy characteristic of Dharma democracy is shown by Lin (2009) as a form of the government-sponsored consensus conference, which is Taiwan's model of citizen participation (although, again, studies of the "outside" of political life do not explore the "inner side" that bring up the model). Concerning society-state relations, Farrelly from Queens University, Canada, explained Zurn's theoretical concept of deliberative democracy. According to Zurn's explanation in Farrely, (2009), deliberative democracy adheres to the critical position of the reasons-responsiveness of the state.

About the size or the size of the participants. The deliberation model, which has initially been small in scope (local areas of decisionmaking referred to in Fung's work $(2003,2004)$, has now been expanded to a city-scale: "Cities have been the privileged loci for deliberative experiments (Melo \& Baiocchi, 2006). In this urban political context, three (3) levels of locus deliberation have been practiced: (1) the city level and the most widely publicized is the Porto Alegre experiment in Brazil—which was then replicated in 170 municipal cities throughout Brazil (2) the community level ( such as in the NRP (or Village Revitalization Program in Minneapolis in the US; and (3) practice in sectoral development, namely the health sector in Brazil by forming a health sector council to plan health development.

Another critical issue is the importance of voluntary associations. The push towards direct involvement in local government was again fueled by disappointment with the poor performance of local governance mechanisms. In Canada, reformist peasants from several provinces adopted a procedure for drafting citizen-based legislation: "'popular dialogue' helped shift institutional settlements in favor of more direct control." The importance of CSOs or NGOs/ORMAS or the third sector for the democratization and efficiency of local governments has been discussed, among others, by Jan Bucah and Brian Smith (2000). The third sector is the "structure of non-supramental organization on the part of local governance the so-called third sector of voluntary bodies, not for profit organizations, community groups, and other local associations" (Bucek \& Smith, 2000, p. 16). Fung (2003) traces several vital contributions made by voluntary associations in society (NGOs/Ormas) for improving the quality of democracy. The three (3) 
very relevant contributions mentioned here are (a) by joining NGOs/Ormas, there is a process of increasing socialization of good citizens and democratic political behavior of citizens (civil socialization and political educations) (b) strengthening bargaining power (bargaining power). Community to fight for the public interest ((as a function of interest representation) (c) becomes a bridge for the realization of deliberation and the growth of a practical public sphere (public deliberations and the public sphere, and (d) governance is more open and democratic, and citizen participation is in the flow.

\section{Research Methods}

The method used in this study is a qualitative research method. Based on the principles, data acquisition is carried out simultaneously with developing concept categories for various materials. Materials are taken from secondary data by tracing various civic virtues written in books and scientific journals. The categories are arranged based on the main concepts of democratic culture and social-democratic institutions. The perspective of deliberative democracy theory is used. Namely, (1) Involvement of a broad segment of society, (2) deliberation, (3) Public spiritedness, (4) With the development of concepts, it is possible to formulate an empirical generalization.

\section{Results and Discussion}

Wajo Tribe Civic Virtues. From the notes of Zuhro et al. (2009), Wajo is one of the areas of the Bugis people. The following is described by Zuhro et al.: "The area is located in the middle of South Sulawesi Province with an area of only $4 \%$ compared to the area of South Sulawesi Province. One of the fascinating villages to study is Tosora Village. In this village, one can also find traces of The first entry of Islam in Wajo was in the form of the ruins of an old mosque located right behind the Tosora Village Head Office".

Based on various studies recorded in pre-Indonesian history, the "Wajo people" have political values based on communes. Moreover, on top of the citizenship of the community, the Wajo Kingdom was founded. The dynamics of interaction between kingdoms in the archipelago have led the "Wajo people" to convert from animism (paganism) to Islam. With this transformation, two (2) fundamental things have an effect: First, in terms of doctrine, and second, the process of internalizing the values of justice and equality in Islamic doctrine into the culture. In this case, the religious doctrine level of the Islamization process, which then took place, is said to have been contextualized with the cultural system of the Wajo people, and its characteristic Islam is called accommodative Islam. Hasanuddin (2013), with a study based on several studies, mentions the traces of early Islamization (1610) (a) Relics of the Old Mosque in Tosora, Majauleng District, (b) Relics of various Mushollas, (c) Gedong (Ammunition Building).

In addition, there is also a tradition of carrying out political contracts. "The word Wajo was used as the identity of the community about 605 years ago, which was independent and sovereign at that time, under the shadow of the bajo tree, a social contract was held between the people and the traditional leaders and agreed to form a Wajo craft".

Another civic virtue of the culture of the Wajo people is the value of equality, namely that citizens are equal among citizens. Also, in leadership. As Zuhro et al. (2009) described, the practice concerns selecting leaders who are considered to have the competencies needed by citizens' lives. This person came from an ordinary person. Second, there is the practice of deliberation together. At that time, all problems that arose in the group were discussed together under a Bajo tree. Which later became the origin of the term wajo-wajo.

Third, there is a form of political participation in protests if the King/Leader is unfair. Fourth, with the dynamics of government experience with kings that may be unfair, there is a developmental stage in determining someone to be king. Namely with the introduction of the agreement (political contract). The king's appointment with this contract then "became a hallmark of the Wajo Kingdom which distinguished it from other Kingdoms in South Sulawesi."

The first concerns the principle of deliberation with Saiyo Saketo: by explaining that "Different opinions for individuals are experienced in community life, but a solution is sought by deliberation to reach consensus, decisions may be unanimous (acclamation), but maybe flat or narrow (through voting), regardless of the process. Decisions are made if, after consensus, the decision must be implemented by all parties.

The second relates to a place for deliberation known as a relatively large open area, Kurisu Salapan (seat eight) or Medan nan Ayahaneh or a sizeable hot field (a stone hall, a row of stone chairs. At this stage (pre-Hinduism to influence in), the democratic procedure is direct democracy. The following development is the implementation of representative democracy. "The life of deliberation then developed until later times, namely the Islamic and colonial times. The increasingly complex life of society also caused many problems in society that had to be decided through deliberation. When life became more complex, society entrusted the affairs to the penghulu, the leaders. These penghulu or customary holders then convene to discuss various matters such as the affairs of the Nagari government, resolve and hear cases, and others.

In the study of Zuhro et al., it is noted that considering its position as the center of birth and cultural and social development of the Minangkabau community, ... this makes Nagari Minangkabau ... as an object of observation to explain the values and behavior 
of democracy in the area. Nagari Minangkabau is one of the oldest Nagari in Sum-Bar. ... The history of the Minangkabau Nagari is fascinating to note because it is part of the story of the formation of the old Nagari in Sum-Bar."

Nagari Minangkabau is located in Batusangkar City, with its agriculture, fisheries, and animal husbandry economy.

From various studies by experts, Zuhro et al. noted that the Minangkabau government system, which was initially been characterized by two (2) models, namely the democratic model from Bodi Chaniago's philosophy and the aristocratic model of Koto Piliang's philosophy, was later more democratic - "Minangkabau is considered to have been widely absorbed. In the Bodi Chaniago custom, the fusion of the two traditions is thought to have started since the entry of Islam into the Minangkabau realm. Furthermore, referring to the classical sociologist Mochtar Naim, Zuhro, et al., wrote: "Islam is considered to bring egalitarian teachings that view people, not from position and descent, but piety to Allah." France and the American Revolution. Egalitarian values have also been practiced by the leadership of the Prophet Muhammad S.A.W in the 6th century AD.

Another civic virtue is a political institution in customary authority: the highest structure is the penghulu. It is said that "he was chosen among the members of his tribe and required to guide and nurture his tribe. His successor is his nephew (nephew/or son of his sister. In carrying out his duties, the penghulu is assisted by one or several young datuks called penghulu ... (penghulu penongkat) ..."

Another variant comes from the inheritance of the koto piliang authority, which includes four (4) authorities as collective leaders, called urang ampek jinih. (1) penghulum, (2) priest, namely the authority of religious knowledge, (3) manti, and (4) Hulubalang, namely customary authority. In addition to the variant reflecting collective leadership, the mainstream variant seems to be the triad leadership variant in the Nagari system, called the furnace tigo sejarangan. "The penghulu leads in the social system, the ulama in the religious field and is intelligent (intellectual) in the fields of socio-economic life and education."

The first case is among the community in Bungkul Park, Surabaya. The practice of deliberative democracy is not an import. The practice of interaction and talks between communities in a park in Surabaya, Taman Bungkul, is an example. For many Indonesians, the phenomenon in Bangkul Park is mediocre, nothing exciting or unique. However, for observers who understand the failure of representative democracy and who master the latest theories about DD and the theory of public space from Habermas, we hope we will highly appreciate the phenomenon in Bungkul Park. Faridah da Rahman, bicycle communities, carried out field research on this matter, and others talked, discussed, and then got good ideas, taking action options, and bringing them to the local government to influence political policies and become the output of state policies. The location is more than $3000 \mathrm{Km}$ wide, among others, surrounds Jalan Taman Bungkul and Jalan Raya Darmo. The concept of the Surabaya City Government is for green open space. During the past three years, Bungkul Park has much more cared for local tourism. Various residents who travel can also buy food and drinks from vendors who can sell in Bungkul Park. Included among the contributors to cultural activities are TV shows from local TV SBO. On Sundays, with a higher volume of visitors, the Jawa Pos and PT Telkom newspapers also held entertainment.

One of the communities that were formed was the SENAPATI (True Patriot Ancient Bike) community. This community discusses various casual topics to local and national news. During the research by Faridah and Rahman, the chairman of SENOPATI was a retired DPRD member.

One of the steps taken is to match the aspiration for the City Government to provide a few special lanes for onthel bicycles (moved by pushing the pedals of the bicycle, relying on physical exertion). The conversation between members of this community began with a hit-and-run incident on a cyclist on Jalan Darmo that befell a member. The results of these residents' conversations then went to the next stage, namely conveying their aspirations to the City Government, Mayor Ibu Tri Rismaharini. This aspiration with an official letter to the City Government then received a positive response, in the form of opening the leftmost lane as a particular lane determined by the Surabaya City Government. Faridah \& Rahman wrote, Bungkul Park "..., can also be used as a place to realize deliberative democracy such as discussing state policies that are less precise, (but) more profitable for groups and at the same time play an active role in determining every policy issued by the government".

This particular bicycle lane project was scheduled to start on January 1, 2012. However, it was only realized in May 2012. The existence of a paint company sponsor who attached a trademark along the road along Darmo (Darmo Street)-Urip SumohardjoBasuki Rahmat-Governor Suryo had also become a nuisance. or an obstacle for some members of the community. They questioned the corporations that contributed to this project. Nevertheless, in the end, from the members' discussions, the community did not officially object. Because it is in the public interest that it is finally acceptable.

As reported by Farida and Rahman (2013), the practice of deliberative democracy is not an import. The practice of interaction and conversation between communities in a park in Surabaya, Taman Bungkul, is an example. For many Indonesians, the phenomenon in Bungkul Park is mediocre, nothing exciting or unique, but for observers who understand the failure of representative democracy and who master the latest theories on TDD, the theory of public space from Habermas would appreciate it highly. The phenomenon in Bungkul Park. The two researchers noted that bicycle communities, Etc., had good conversations and brought them to the local government to become public policy outputs. 
So, we are forced to see and interpret the phenomenon of Taman Bungkul as an out-of-the-box way of thinking. We are using the "import" theory lens because our social sciences are far behind and have not yet developed social sciences indigenous. We are very grateful that some of our citizens can develop a democratic identity according to social piety/cooperation that grows from the values noble nation of Indonesia. These citizens do not need to throw away "original goods" and then use "imported goods."

Rendra Wahyu Kurniawan's research reveals the history of the function of the square: from the function of public space when the Mataram Kingdom ruled Tulunagung Regency to being a location for street vendors during the independence period, and now its function is returned as a public space. However, during the Dutch colonial period, the construction of a fence or barrier that surrounded the field became a symbol of limiting the rulers and the people. Also built a prison near the square. Now the prison has been relocated to the south of the Heroes' Cemetery. Besides being built for children's play facilities, the Tulungagung District Square is planted with shady trees and decorated with ornamental plants. "During the day, hundreds of pigeons become entertainment for visitors who want to provide food in the form of corn... while in the afternoon, some visitors take advantage of playgrounds and outbound...." Among these communities are the Breaking Rooster Crew, Skate Board Community, and BMX Bike Lovers. There is also a community of reptile and weasel lovers.

Kurniawan described various communities and residents of Tulungagung in building public discourse as follows:

"The emergence of various creative groups and communities from young people of Tulungagung Regency such as the Young Union Union (PSM), Tulungagung Grafitty Community, Creative Young Community (KMK), Etc., is one of the results of the successful use of the square as a public space. Although some communities are not involved in politics, they often respond to political issues in the area when they gather. This is a form of building political participation from young people who are members of each community".

The Pendopo (the regent's official residence) is also used to provide a forum to capture aspirations. In each forum, it is ensured that there is a representative from each village. So, the aspirations that are absorbed can be fully absorbed. At the same time, the practice of deliberation in public spaces is also not only in the square of Tulungagung Regency but also in public spaces in several coffee shops: "..., the flood of coffee shops in Tulungagung Regency has also become a new location that can be used as a public space for the community".

Second, the practice of political contracts that has been practiced by one of the studied ethnic groups is very advanced. With this social capital, there is hope and opportunity that the current political contract would also be of higher quality and be obeyed by the parties. Third, the practice of family deliberation at the community level is social capital in grassroots communities. Moreover, social capital produces political interactions that can influence local government policies (in the case of the community in Taman Bungkul Surabaya) and is also the initial capital to be used as procedures and developed beyond the interests and concerns of the internal community. With the development of attitudes and behavior as citizens of the city, this social capital can foster peaceful and quality political participation to influence local government public policies.

\section{Conclusion}

The noble values related to democracy exist significantly in the ethnicities discussed and practiced by the communities. Likewise, the traditional social institutions studied are democratic political institutions that have grown and developed. By applying the concepts in Deliberative Democracy Theory, this study notes the potential among ethnic groups in Indonesia to strengthen democratic practices based on cultural wisdom.

The adoption of modern (Western) values and institutions in democracy should take into account the existing cultural treasures of democracy. For this purpose, regulation, and adoption of modern democracy need to consider the complementarity of local democracy that has long been growing - especially the avoidance of the Central Government from making uniform policies in democratic procedures.

Funding: This research received no external funding

Conflicts of Interest: The authors declare no conflict of interest.

\section{References}

[1] Abdullah, T. (2014). Tun Sri Lanang and the Malay Natural Cultural Association. Journal of Society and Culture. Vol 16 (1) $2014,1-26$.

[2] Bucek, J \& Brian S. (2000). New Approaches to Local Democracy: Direct Democracy, Participation, and the 'Third Sector. Environment and Planning Governmental Policy. Vol 18, . 3-16

[3] Christomy, T. (2006). The Coffee Shop and Habermas Thoughts in Discourse, Journal of the Humanities of Indonesia, 236-240 (Brian Cowen's Book Review, the Social Life of Coffee: The Emergence of the British Coffeehouse. New Heaven \& London: Yale Univ Press, 2005).

[4] Cohen \& Joel P. (2013). Deepening Democracy Institutional Innovations in Empowered Participatory Governance. New York: Verso, 241 
[5] Dryzek, J. S. (2005). Deliberative Democracy in Divided Societies: Alternatives to Agonism and Analgesia. Political Theory. Website: https://openresearch-repository.anu.edu.au/bitstream/1885/41769/3/Dryzek_divided.pdf Accessed 8 May 2017

[6] Faridah \& Rahman A. (20130. Use of Bungkul Park as a Public Space in Realizing Deliberative Democracy (Case Study of the Senopati Community). Moral \& Citizenship Studies, Vol I (1), p. 116-132

[7] Farrely, C. (2009). The Deliberative Democracy and the Institution of Judicial Rev in Social Theory and Practice, (Proquest Sociology. Apr 2009 Vol 35 No. 2), in "Book Review", Christopher F Zurn, Deliberative Democracy and the Institutions of Judicial Review. New York: Cambridge University Press.

[8] Fung, A. (2003). Associations and Democracy: Between Theories, Hopes, and Realities, Annual Review Sociology. http://www.archonfung.net/papers/FungAnnRevSoc03.pdf, pp. 515 - 539.

[9] Indar A, I. (2009). Good Governance and Regional Development in the Frame of Local Values: A Study of Bureaucracy and Social Change in Kab, Wajo Government: Journal of Governance Science Vol 2 (1), . 63-79

[10] Liu, S. (2008). Undomesticated Hostilities: The Affective Space of Internet Chat Rooms across the Taiwan Strait, in Positions: East Asia Cultures Critique, Vol 16 (2), Fall 2008 435-455.

[11] Melo, M. A. \& Gian P. B. (2006) Deliberative Democracy and Local Governance: Towards A New Agenda, International Journal of Urban and Regional Research, Vol. 30 (3) September, $578-600$

[12] Morfit, M. (1981). Pancasila: The Indonesian State Ideology According to The New Order Government. Asian Survey, Vol 21 (8),. $836-853$.

[13] Siregar, I. (2021). Verbal Communication of Schizophrenic Patients Due to Neurotransmitter Distortion.QALAMUNA: Jurnal Pendidikan, Sosial, Dan Agama, 13(2), 543-556.

[14] Siregar, I. (2020). Exploration and Implementation of the Cultural System as a Solution to National and State Problems. http://repository.unas.ac.id/id/eprint/811

[15] Siregar, I. (2021). Analysis of Betawi Language Interference on the Morphology of Adolescent Speech in Jakarta. Journal of Humanities and Social Sciences Studies, 3(8), 54-60. http://doi.org/10.32996/jhsss.2021.3.8.7

[16] Siregar, I. (2020). Geografi Leksikon Betawi. Jakarta: LPU Unas

[17] Siregar, I. (2021). Epistemological Challenges Against Sociolinguistics. International Journal of Linguistics Studies, 1(2), $37-42$. https://doi.org/10.32996/ijls.2021.1.2.6

[18] Siregar, I. (2021). The Existence of Culture in its Relevance to the Dynamics of Globalization: Bahasa Indonesia Case Study. International Journal of Cultural and Religious Studies, 1(1), 33-38. Retrieved from https://www.al-kindipublisher.com/index.php/ijcrs/article/view/2285

[19] Siregar, l., Rahmadiyah, F., \& Siregar, A. F. Q. (2021). Linguistic Intervention in Making Fiscal and Monetary Policy. International Journal of Arts and Humanities Studies, 1(1), 50-56. https://doi.org/10.32996/ijahs.2021.1.1.8

[20] Siregar, I., Siregar, R. (2021). The Relevances between Poda Na Lima Philosophy with Islamic Perspective. Budapest International Research and Critics Institute (BIRCl-Journal): Humanities and Social Sciences, 4(4), 11746-11754. https://doi.org/10.33258/birci.v4i4.3240

[21] Sulistyono, T. S. (2015).. Multiculturalism in the Perspective of Coastal Culture. Agastya's Journal. Vol 5 (1), January, 1-18

[22] Suparlan, P. (1975). Javanese Ethnic Association 